\title{
Buddhists' Motivations for Revisiting Religious Temples in Malaysia
}

\author{
Teo Shao Zhen, Siti Hasnah Hassan, and Osman Mohamad
}

\begin{abstract}
This study aims to unravel the motivations of Malaysian Buddhists in revisiting religious temple. Although there are various sacred sites for Chinese believers, but less writers have tried to draw a systematic research into Chinese religious tourism in Asia. Empirical results from this study discovered that religious value, personal and spiritual growth, as well as the need for social interaction have significant effects on revisit intention. However, the aspects of achievement and cultural value were found to be insignificant. By understanding the underlying motivations, the businessmen and government will be benefited when participating into the religious tourism sector.
\end{abstract}

Index Terms - Malaysian Buddhist; motivations; religious tourism; revisit intention.

\section{INTRODUCTION}

Individuals who visit solely or with a group of people to a religious place for leisure, missionary or pilgrimage reasons can be said to perform a religious tourism [4]. There are various and multiple motivations that prompt the individuals for a religious trip, however, one of the oldest inspirations were the religious motives [1], [17], [34]. [10] defined religious tourism as the travels that are similar as leisure and recreation in a rigid sense, which comprises of religious motives. According to [13], a travel that was motivated spiritually usually been centralized around penance, meditation, and prayer while tourism was merely a hedonistic circumstance. On the other hand, the journeys that have been inspired by religious faith is believed to possess a lot of similar characteristics as the tourism travels, with the only disparity being the act of consumption [26].

According to [28], the biggest religion in 2015 is Christian. They made up $31 \%$ of the Earth's population, equivalent to 7.3 billion people. This is followed by Muslims with 1.8 billion (24\%) people in the world, people who do not subscribe to a religion $(16 \%)$, Hindus $(15 \%)$ and Buddhists $(7 \%$.) The rests are Jews and members of other religions. Nonetheless, [13] claimed that the exact number of Buddhists is hard to calculate because it merges with other beliefs systems such as Taoism and Confucianism.

Most religions have a strong culture of pilgrimage. Muslims travel to Mecca, Saudi Arabia during the Hajj

The authors would like to thank Universiti Sains Malaysia for funding this research under the Research University Grant No. 1001/PMGT/816211.

Teo Shao Zhen, School of Management, Universiti Sains Malaysia, Peang, Malaysia (e-mail: shaozhenteo@yahoo.com).

Siti Hasnah Hassan, School of Management, Universiti Sains Malaysia, Penang, Malaysia (e-mail: siti.hassan@usm.my).

Osman Mohamad, Multimedia University, Cyberjaya, Selangor, Malaysia, (e-mail: osman.mohamad@mmu.ed.my). pilgrimage season which contributed to the world's largest form of mass pilgrimage [3]. While the religious places for Christians are related to the historically based narratives and sites such as 'El Camino de Santiago' or 'The Way of Saint James' in north western Spain [1] that relate to later saints or miracles [9]. For Buddhism, Southern Nepal and Northern India are the most important places for religious tourism. The four main religious sites for Buddhists are Lumbini, Bodh Gaya, Kusinagara and Sarnath, which locate between New Delhi and Rajbir, the area where Gautama Buddha stayed and preached Buddhism [11], [32].

The pilgrimage sites for Buddhists was established after Lord Buddha death, including the one that had been suggested by the Buddha himself. In addition, most of the religious sites are associated with Buddha's legendary visits to the island of Sri Lanka [13]. The increase of worldknowledge has contributed to the discovery of more sacred sites. Although some of them had lost their spiritual meaning with time, they still attract immense interest. Example of such places are the Angkor Wat in Cambodia, sacred mountains in China, and Stonehenge in England [31].

There has been an increase in religious tourism in recent years. An explanation for this trend is modern individuals want to acquire life achievements. They are also increasingly inquisitive in making sense about the world and are trying to find a sacred meaning for life [31]. These lead them to the holy sites to join the rituals. Current religious tourists are more likely to travel to the religious sites in the world, as indicated in their religion [31]. Religious tourism affects individuals' by giving meaning to life, helps them to discover themselves and maintain good mental health [37]. Indeed, religious tourism is developing rapidly; 300-330 million tourists travel to holy sites every year [1].

As tourism has advanced into a global social and economic phenomenon, there is an increasing number of people who travel around the world for the religious or spiritual intentions [1], [25]. The increasing accessibility of holy sites has profited the international tourist market. Such economic potential has been recognized by governments and other agencies and they have been promoting holy places to tourists [25]. Nepal, for example, is actively promoting Lumbini, the birthplace of the Buddha [11], [13], [32]. Since 1997, Lumbini has been a UNESCO World Heritage Site and is explored by thousands of Buddhists yearly, making it among the most famous sites for Buddhist pilgrimage in Nepal [11], [13], [32].

In a nutshell, the degree of individuals' revisit intention to sacred sites should be understood and fulfilling their expectations is pivotal [1], [31]. The revisit intentions can be diverse and the religious travellers who are taking such a journey might waver in their initial motivations [24]. For 
instance, the initial motivation of the religious tourists for undertaking a pilgrimage might be overlooked, while others may be inspired by merit or repentance [1]. Differing motivations for religious tourism ought to be understood to improve religious tourism sector [24]. The reasons why individuals still revisiting to sacred places even though the places pose a higher risk of danger should be studied [31].

\section{Religious TOURISM IN MALAysia}

Malaysia is one of the most developed countries in Islamic tourism in the Southeast Asian region. In 2012, about 5.44 million Muslim tourists visited Malaysia compared to 5.22 million in 2011. In 2013, Malaysia had more than five million Muslim tourists from Muslim countries [33]. This happen due to the support of Malaysian government to promote religious tourism in Malaysia [19]. Apart from that, the Buddhist and Hindu tourism still have the potential to be developed in Malaysia. Nevertheless, there is a lack of research being done on that particular sector.

[13] stated that Buddhism has been considered as one of the world's best religion. Buddhism is also known as 'The Way'; it guides its followers to the middle way between devotion to the pleasure of the senses and selfmortification. This belief was pioneered by Siddhartha Gautama, also known as Buddha. The devotees of the Buddha follow the teachings and insights of the Buddha on the ways of life. The aim of Buddhism is to achieve a state of consciousness known as the Enlightenment.

Normally, some of the people in south and eastern Asian regions practice Buddhism, and now Buddhism is slowly emerging to the Western countries. Therefore, those regions usually attract more foreign travellers to visit the Buddhist sacred places. With regard to this, developed or developing countries such as China, Thailand and India are trying to develop Buddhist tourism in their country [22], Malaysia should also develop its Buddhist tourism to draw more visitors from the neighbouring countries. The sacred temples that have been visited by most tourists all over the world in Malaysia which are subjected in this study are Kek Lok Si Temple, Snake Temple, Dharmikarama Burmese Temple, Wat Phothivihan and Thean Hou Temple.

Nowadays, entrepreneurs seek opportunities and gaps in the market for new inventions, services or products. With the majority of the population practicing a belief system, religion sector should be explored to increase a country's economic status [1]. Some entrepreneurs are aware of this opportunity. This is reflected in a growing trend of religious tourism attractions in most countries [31].

In conclusion, the religious tourism sector is one of the most understudied areas in tourism research despite being a worthy economic sector [1], [19], [25], [31]. It is quite surprising that religious tourism has been overlooked by the past scholars with the increasing market opportunities in this particular sector [1], [19], [25], [31]. Therefore, this study aims to understand the motivations affecting revisit intention to religious temple from the Buddhism perspective in Malaysia.

\section{LITERATURE REVIEW AND HYPOTHESES}

Religious tourism can be defined as a trip that has been inspired by religious faith, externally to a holy place and internally for spiritual motives and internal cognition [1]. Religious tourism involved the ancient practices where religious tourists travelled solely or in a group for religious faith for a period of time [4], [31]. Those travel includes pilgrimages, missionary trips and visiting sacred places. Apart from that, other personal reasons such as seeking pleasure may also motivate people to go for religious travel [4]. Prior to the 19th century, a religious travel was anticipated to be an adventurous journey that required hardship in order to obtain a sense of spiritual satisfaction [31], [38]. However, religious tourists nowadays have emerged and the reasons for religious travel are changing [1], [2]. The experience of religious tourism was seen as a way to strengthen the relationship with people of similar mind and faith, reinforcing beliefs and ties between the devotee and the divine [38].

Furthermore, there is spiritual sites and associated services for religious tourism, which were explored for secular and religious motives. Shrines and pilgrimage sites were two distinct sacred sites that were determined by a scholar [31]. According to [31], shrines include sites where a historical remain or image was 'honoured'. Meanwhile, pilgrimage sites were sites where it was believed that a miracle had happened, may still occur and might occur again. For example, Bodh Gaya in India is the site where Gautama Buddha achieved unsurpassed, supreme Enlightenment. Currently, there is an increasing trend towards developing the purpose-built religious tourism attractions on non-sacred sites [31]. For example, the 'Wat Mae Kaet Noi Temple' in Thailand that was built to depict 'naraka' or 'hell' in Buddhism. The frightening statues were built as a reminder for believers before going against the Buddhism teaching.

Moving on, [31] mentioned that despite the resemblances and disparities between these types of tourism, the underlying theme for religious tourism is typically still 'travel'. A religious tourism typically has five characteristics [31]; (1) Voluntary, temporary and unpaid travel, (2) Motivated by religion, (3) Supplemented by other motivations, (4) The destination is a religious site (local, regional, national or international status), and (5) Travel to the destination is not a religious practice. In conclusion, current research can provide valuable insights to businesses and commercial analyst for the sound market analyses in this particular sector [4], [27].

\section{A. Religious Value}

The religious journey has been integrated in the history of mankind where it is regarded as the oldest form of tourism [1]. While the prime and fundamental psychological motivation of this kind of travel were believed to be the religious value and faith although there were other motivations that prompt the masses to travel [1], [4], [23], [37]. According to [31], the actions of an individual such as taking the religious journey is profoundly influenced by their religious faith, beliefs, and practice. Religious tourists 
were believed to be inspired by a sense of obligation and duty rather than a hunt for amusement and leisure [17], [23]. [23] further illustrated that some individuals visited holy sites to retain their individual character and identity, others to suffice the feelings of nostalgia, to experience spiritual transcendent or to carry out the teachings of the religious faith. Past studies conducted by [37], [19] discovered that religious beliefs influenced people to become religious tourists. The behaviour of the other religious tourists at the temple as well as the genuineness of the holy experience were observed by religious individuals, which then affected those individuals to perform a religious trip [37]. However, the study by [1] discovered that religious value were not the prime motivation for religious travel. Results indicated that religious motive in fact has the lowest averages factor for religious tourism.

H1: Religious value will be positively related to the revisit intention to a religious site.

\section{B. Sense of Achievement}

[15] defined sense of achievement as the pride of completed the difficult and worthwhile situation successfully. Humankind works hard to have a good employment, accomplish high educational level as well as social status in life. Typically, people are stimulated by achievements [31]. People are motivated to live independently, and they are constantly challenging and improving themselves. Therefore, individuals who visited religious site were inspired to gain personal satisfaction and a sense of achievement due to the hardship along the journey. Sometimes, religious trip has been regarded as an opportunity for personal improvement, wealth creation, adventure as well as intellectual, practical and spiritual discourse. Sense of achievement has been found to be positively related to revisit intention in a study by [6] in Malaysia. The Muslim tourists have been motivated by the achievement factor to perform a religious travel. On the other hand, modern-day pilgrimages also offer chances for adventure which could contributed to the sense of achievement. For instance, some holy places are situated in rural or remote areas where the religious tourists are required to travel by foot for a few days before arriving the destination. This is due to the reason that those religious tourists feel responsible to achieve a certain degree of prostration along the journey.

H2: Sense of achievement will be positively related to the revisit intention to a religious site.

\section{Personal and Spiritual Growth}

Moving on, personal and spiritual growth is believed to be the motivation for religious tourism [31]. Religious tourists may perceive difficulty in the journeys offered a chance for growth and development of the survival skills. For instance, although the crowd surges at the Hajj lead to hundreds of deaths and injuries amongst tourists in the past few years, however, there is still innumerable Muslims undergoing the Hajj every year [31]. This is because they were inspired to build their survival skills and personal growth, which are regarded as a form of spiritual growth. There are two types of rewards, namely intrinsic and extrinsic rewards. Intrinsic rewards described the enhancement of spirituality or self-actualization while extrinsic rewards include recognition or status gained. Perception is correlated with the effort and reward. If an individual trust that enduring the hardship or hassles of pilgrimage will enhance them spiritually, then that will inspire them to travel to religious site [1], [19], [24], [31], [37], [40]. A research concluded that there is not much tourists who travel solely for religious purpose. Meanwhile, spiritual reasons were more common [24]. According to [37], individuals seek for personal and spiritual growth were because of the shallowness and inauthentic experiences of their daily lives.

H3: Personal and spiritual growth will be positively related to the revisit intention to a religious site.

\section{Cultural Value}

Cultural value also may motivate people to go for religious travel all over the world [1], [2], [4], [19], [37], [40]. The difference between cultural and religious tourism is hard to differentiate. This is due to the reason that archaeological memorials and monuments usually have some meanings to the religion and cultural value, where these historical and cultural heritage are the backbone of the tourism sector. According to [4], there is some similarities between the cultural and religious tourism. Where religious tourists might integrate both elements or intentions while travelling for religious purposes. [31] further explained that Wailing Wall in Jerusalem may hold a different significance for different religious believers, Jews may see it as a religious place for them, but Buddhists may regard it as a cultural site. From an anthropological perspective, there is no clear division between religion and culture as culture is all-encompassing. Individuals differentiate between the cultural and religious place by regarding the latter as more religious. Nonetheless, cultural and religious places have always been referring to the same essence [1] - [2], [4].

On the other hand, cultural value can be categorized as a pull (external/extrinsic) factor in the push-and-pull theory [37], [40]. Religious tourists are attracted to exotic customs and atmosphere of a particular place [40]. Such intense religious atmosphere could guide them in discovering their inner selves, similar to temples [37]. The religious site also may be architecturally significant, culturally important or simply 'famous for being famous' [35]. In addition, some tourists expected to gain the cultural experiences and knowledge by visiting the holy sites [35], [37], [40]. For instance, the cultural events happening at the religious site [19] and the natural environment where the temples are located [37] may act as the motivator for the religious tourists to visit the holy sites.

H4: The cultural value will be positively related to the revisit intention to a religious site.

\section{E. Need for Social Interaction}

Normal individuals demand for affection, social interaction as well as a sense of belonging. The believers performed religious tourism to gain emotional support from the people from various background but with the same belief at a religious place [37]. The trip also has the potential to strengthen the ties, beliefs and relationship with like-minded people and the divine [38]. Besides that, [31] argued that those who want to interact with like-minded people may visit the holy places in a tour group. In similar situations, the 
individuals who travel solely or within s small group usually still a part of a bigger group travelling to the same destination. This is because group travel is a bonding process that could potentially add the social element into the spiritual experience which could make the religious journey more meaningful and beneficial [8]. Normally, group travels can develop emotional connection and a sense of fondness along the trip. Such connection assembles people from the same belief and inspires them to travel in group. Once other needs are satisfied, people usually aimed to attain a higher esteem in their religious community.

H5: The need for social interaction will be positively related to the revisit intention to a religious site.

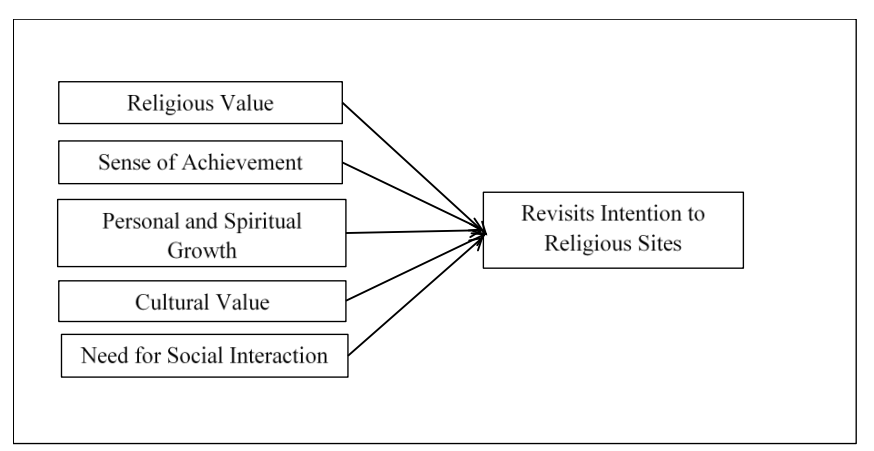

Fig. 1. Research Framework.

\section{Data Collection Method}

A self-administered questionnaire was created to gauge the motivations of the Buddhist believers to revisit the temples in Malaysia. The questionnaire was distributed and collected from Buddhists in Malaysia who had visited temples in recent years. Furthermore, the questionnaires consisted of three different sections. Section A was made up of screen questions to identify the relevant respondents for this research. Meanwhile, Section B consisted of the motivations that affected their visits to the religious site. For this section, the instrument was developed on the basis of the modification of items from previous literature, namely, constructs for Revisit Intention to Religious Site [7], [24], Religious Value [1], [30], [37], Sense of Achievement [29], [40], Personal and Spiritual Growth [20], [40], Cultural Value [1], [16], [19] - [20] and Need for Social Interaction [5], [21], [29]. Section C was regarding the demographic profile of the respondents (age, gender, education level, employment status and monthly income). The independent variables were measured using the 5-point Likert scale ranging from 1 (strongly disagree) to 5 (strongly agree). On the other hand, the dependent variable was measured using the 7-point Likert scale ranging from 1 (strongly disagree) to 7 (strongly agree).

The unit of analysis is the Buddhists who had visited the temples in the recent years for religious purpose. Therefore, a non-probability convenience sampling method and purposive sampling technique were employed in this study. Purposive sampling method was utilized because this study focuses on Buddhists who had travelled to holy temples for religious reason. Another reason is that there is an unknown number of Buddhists living in Malaysia and it is not possible to acquire the exact number and size of the targeted populations. Hence, the purposive sampling method assists respondent selection based on the topic of study. Purposive sampling provides an alternative in the selection of the targeted population. Thus, the final number within the population was estimated based on the rule of thumb; the minimum number of respondents was a five-to-one ratio of the number of latent variables to be tested. The data collections were conducted using online questionnaire and distributed through Facebook and Chinese Cari forum. A total of 158 usable survey forms were collected and coded for the data analysis using SPSS 24 and SmartPLS 3.0 software.

\section{Data Analysis And Results}

\section{A. Demographic Profile of the Respondents}

The demographic profile of the respondents is presented in Table 1. There were more females $(59.5 \%)$ than males $(40.5 \%)$ in this study. With respect to age, $40.5 \%$ of the sample were below 25 years old, followed by those between 25 and 34 years old (26.6\%). For education level, most of the respondents $(55.7 \%)$ had a degree, while $1.9 \%$ of them were Ph.D. holders. Moreover, $43 \%$ of the respondents have a full-time job and $3.2 \%$ of them had a part-time job. In addition, $63.9 \%$ of the respondents went to religious sites with their family and only $3.2 \%$ went with their children. Results also indicated that $26.6 \%$ of the respondents did not have any source of income but $14.6 \%$ of them were earning RM5000 and above per month. According to the survey, the most visited temple in Malaysia is Kek Lok Si Temple, in which 46 respondents have been there at least once in recent year. Then, it is followed by Wat Photivihan (15 respondents), Thean Hou Temple (10 respondents) and Dharmikarama Burmese Temple (1 respondent). However, there were 86 respondents visited other temples in Malaysia as well.

TABLE I: DEMOGRAPHIC PROFILE OF THE RESPONDENTS

\begin{tabular}{lcc}
\hline Variables and Categories & Frequency & Percentage (\%) \\
\hline Age & & \\
Below 25 & 64 & 40.5 \\
$25-34$ & 42 & 26.6 \\
$35-44$ & 14 & 8.9 \\
$45-54$ & 18 & 11.4 \\
Above 54 & 20 & 12.7 \\
\hline Gender & & \\
Male & 64 & 40.5 \\
Female & 94 & 59.5 \\
\hline Education & & \\
SPM & 31 & 19.6 \\
STPM/Diploma/Matrices & 21 & 13.3 \\
Undergraduate Degree/ Degree & 88 & 55.7 \\
Masters & 8 & 5.1 \\
PhD & 3 & 1.9 \\
Others & 7 & 4.4 \\
\hline Employment Status & & \\
Full Time Job & 68 & 43 \\
Part Time Job & 5 & 3.2 \\
Unemployed & 6 & 3.8 \\
Self Employed & 16 & 10.1 \\
Student & 49 & 31 \\
Retired & 14 & 8.9 \\
\hline & & \\
\hline & & \\
\hline
\end{tabular}




\begin{tabular}{lcc}
\hline Who you were going with & 12 & 7.6 \\
Alone & 5 & 3.2 \\
With Children & 101 & 63.9 \\
With Family & 18 & 11.4 \\
With Partner & 22 & 13.9 \\
With Friends & & \\
\hline Marital Status & 96 & 60.8 \\
Single & 57 & 36.1 \\
Married & 4 & 2.5 \\
Widowed & 1 & 0.6 \\
Divorced & & \\
\hline Monthly Income & 21 & 13.3 \\
Less than RM1000 & 19 & 12.0 \\
RM1000-2000 & 20 & 12.7 \\
RM2000-RM3000 & 19 & 12.0 \\
RM3000-RM4000 & 14 & 8.9 \\
RM4000-RM5000 & 23 & 14.6 \\
RM5000 and above & 42 & 26.6 \\
No Income & & \\
\hline Temple Visited & 46 & 29.1 \\
Kek Lok Si & 15 & 0.6 \\
Dharmikarama Burmese Temple & 10 & 9.5 \\
Wat Pothivihan & & 54.4 \\
Thean Hou Temple & & \\
Others & & \\
\hline
\end{tabular}

\section{B. Measurement Model}

Convergent validity of the measurement model was measured by looking at the item loadings, Composite Reliability (CR) and AVE of the model [12]. Table 2 demonstrated the convergent validity of this study. [12] explained that measurement model can said to have a satisfactory internal consistency reliability when the composite reliability (CR) of each construct exceeds the threshold value of 0.7 . Results indicated that the $\mathrm{CR}$ of each construct in this study were above the recommended threshold value of 0.7 which ranges from 0.914 to 0.963 . Therefore, the items can be said to have satisfactory internal consistency reliability. Besides that, the loadings were also tested to ensure the reliability of the items. A measurement model is said to have satisfactory indicator reliability when the loadings of each item is higher than 0.7. Results showed that all items in the construct had loadings that were higher than 0.7 except for the item CUL5, therefore, CUL5 was removed from the construct due to low loadings. Moreover, the AVE values were recommended to exceed the threshold of 0.5 for all constructs [12]. The AVE scales are required to be larger than the square of its largest correlation with any scale, in which all scales met. Apart from that, discriminant validity was measured in different ways. Table 3 demonstrated the result for the discriminant validity of this study. The heterotrait-monotrait (HTMT) ratio of correlation approach was utilized based on [14] recommendations. All HTMT values in the model were below the cut-off value of 0.85 . This shows that the measurement scales have suitable discriminate validity.

TABLE 2: OVERVIEW VALIDITY AND RELIABILITY OF THE MODE

\begin{tabular}{llccl}
\hline Construct & Item & Loadings & AVE & CR \\
\hline Sense of & ACH1 & 0.894 & 0.830 & 0.936 \\
Achievement & ACH2 & 0.905 & &
\end{tabular}

\begin{tabular}{|c|c|c|c|c|}
\hline$(\mathrm{ACH})$ & $\mathrm{ACH} 3$ & 0.934 & & \\
\hline \multirow{4}{*}{$\begin{array}{l}\text { Cultural Value } \\
\text { (CUL) }\end{array}$} & CUL1 & 0.847 & \multirow[t]{4}{*}{0.914} & \multirow[t]{4}{*}{0.914} \\
\hline & CUL2 & 0.893 & & \\
\hline & CUL3 & 0.904 & & \\
\hline & CUL4 & 0.833 & & \\
\hline \multirow{5}{*}{$\begin{array}{l}\text { Personal and } \\
\text { Spiritual Growth } \\
\text { (PG) }\end{array}$} & PG1 & 0.921 & \multirow[t]{5}{*}{0.839} & \multirow[t]{5}{*}{0.963} \\
\hline & PG2 & 0.900 & & \\
\hline & PG3 & 0.935 & & \\
\hline & PG4 & 0.918 & & \\
\hline & PG5 & 0.908 & & \\
\hline \multirow{5}{*}{$\begin{array}{l}\text { Religious Value } \\
\text { (REL) }\end{array}$} & REL1 & 0.879 & \multirow[t]{5}{*}{0.757} & \multirow[t]{5}{*}{0.940} \\
\hline & REL2 & 0.841 & & \\
\hline & REL3 & 0.857 & & \\
\hline & REL4 & 0.874 & & \\
\hline & REL5 & 0.899 & & \\
\hline \multirow{5}{*}{$\begin{array}{l}\text { Need for Social } \\
\text { Interaction (SI) }\end{array}$} & SI1 & 0.789 & \multirow[t]{5}{*}{0.716} & \multirow[t]{5}{*}{0.927} \\
\hline & SI2 & 0.862 & & \\
\hline & SI3 & 0.889 & & \\
\hline & SI4 & 0.831 & & \\
\hline & SI5 & 0.858 & & \\
\hline \multirow{4}{*}{$\begin{array}{l}\text { Revisit Intention } \\
\text { to Religious Site } \\
\text { (VRS) }\end{array}$} & VRS1 & 0.909 & \multirow[t]{4}{*}{0.809} & \multirow[t]{4}{*}{0.944} \\
\hline & VRS2 & 0.933 & & \\
\hline & VRS3 & 0.877 & & \\
\hline & VRS4 & 0.878 & & \\
\hline
\end{tabular}

Note: CUL5 was deleted due to low loadings.

TABLE 3: DISCRIMINANT ANALYSIS.

\begin{tabular}{lllllll}
\hline \hline & 1 & 2 & 3 & 4 & 5 & 6 \\
\hline 1. CUL & & & & & & \\
2. SI & 0.726 & & & & & \\
3. PG & 0.670 & 0.750 & & & & \\
4. REL & 0.532 & 0.585 & 0.768 & & & \\
5. VRS & 0.626 & 0.699 & 0.755 & 0.686 & & \\
6. ACH & 0.653 & 0.475 & 0.423 & 0.348 & 0.347 & \\
\hline \hline
\end{tabular}

\section{Structural Model}

Moving on, Table 4 showed the path coefficient and tvalue that tests the hypotheses of the research. Figure 2 represents the graphical demonstration of the research model. The path coefficients that are below 0.30 caused moderate effects, 0.30 to 0.60 caused strong effects and above 0.60 caused very strong effects. The predictive power of the structural model was assessed based on the $\mathrm{R}^{2}$ value of the endogenous constructs.

The results for path coefficient and t-value indicated that three of the five hypotheses were accepted in this study. Results found out that the sense of achievement and cultural value were insignificant. While religious value, personal and spiritual growth and need for social interaction were significant to the revisit intention to religious site. The results indicated religious value positively influences the revisit intention to religious sites at a significant level of $p<0.001$. Besides, personal and spiritual growth positively influences the revisit intention to religious sites at a significant level of $\mathrm{p}<0.01$. Meanwhile, the need for social interaction also positively influence the revisit intention to religious sites at a significant level of $\mathrm{p}<0.05$.

According to the results, the adjusted $\mathrm{R}^{2}$ value is 0.571 which suggested that $57.1 \%$ of the variance in the revisit intention to religious sites can be explained moderately by religious value, personal and spiritual growth and the need for social interaction. Another interpretation of the result 
was that the religious tourists were likely to revisit the holy temple again and recommend the temple to their friends and relatives.

TABLE 4: PATH COEFFICIENT

\begin{tabular}{llll}
\hline \hline Path (Hypotheses) & $\begin{array}{l}\text { Path } \\
\text { coefficient }\end{array}$ & t-Values & Decision \\
\hline ACH -> VRS (H2) & -0.052 & 0.812 & Not Supported \\
\hline CUL -> VRS (H4) & 0.144 & 1.640 & Not Supported \\
\hline PG -> VRS (H3) & 0.300 & $2.596^{* *}$ & Supported \\
\hline REL -> VRS (H1) & 0.264 & $3.470^{* * *}$ & Supported \\
\hline SI -> VRS (H5) & 0.215 & $2.392^{*}$ & Supported \\
\hline
\end{tabular}

Notes: Significant at $* \mathrm{t}>1.96$ at $\mathrm{p}<0.05 ; * * \mathrm{t}>2.57$ at $\mathrm{p}<$ $0.01 ; * * * \mathrm{t}>3.29$ at $\mathrm{p}<0.001$.

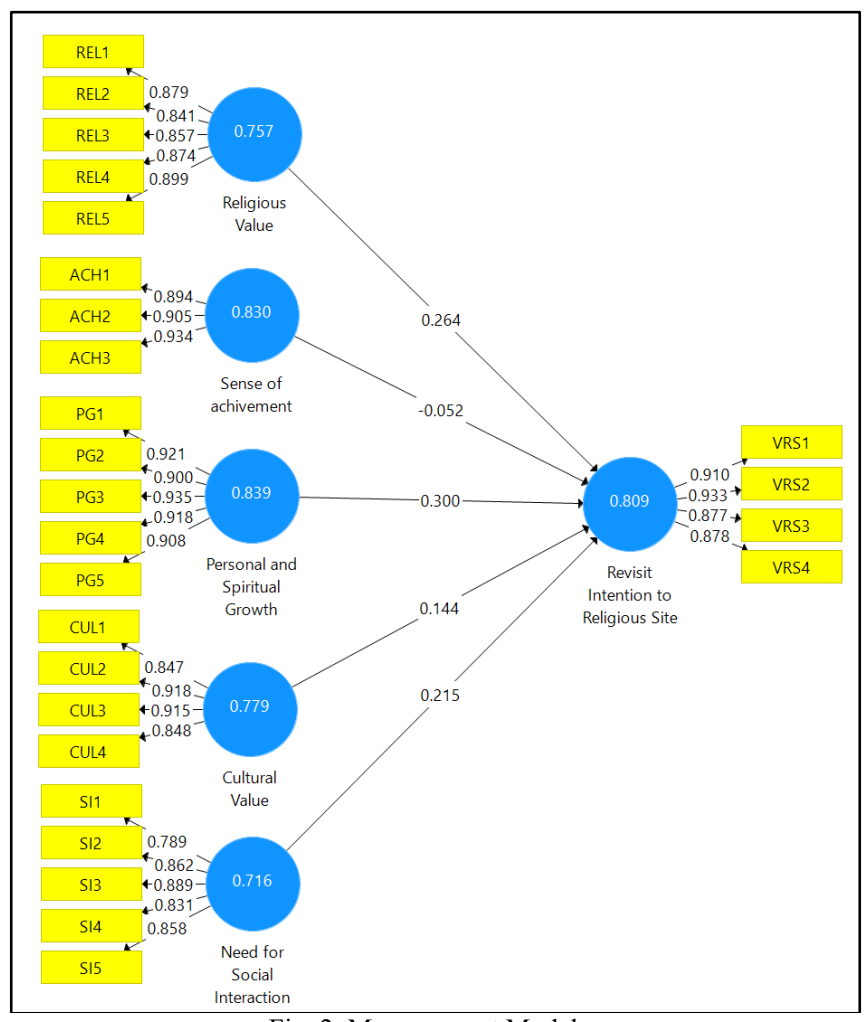

Fig. 2. Measurement Model.

\section{DISCUSSION AND IMPLICATIONS}

This study aims to unravel the Buddhists' motivations of revisiting the religious temple from the Chinese perspective in Malaysia. Empirical results in this study discovered that the religious value, personal and spiritual growth, and the need for social interaction were significant towards the revisit intention to religious temples. Nevertheless, sense of achievement and cultural values were found to be insignificant factors in this study.

Religious value was found to be the strongest motivation to the revisit intention among the Buddhists in Malaysia at a significant level of $p<0.001$. The results indicated that the faith and practice of the religion could deeply motivate the actions and decisions of their believers. [37] also came to the same conclusion where the religious factor was found to be the significant factor. The Buddhist respondents were found to be highly focus on Bodhisattva's responses. According to Pure Precept, Buddhists should follow the teachings strictly to become Buddha in the future. Besides seeking repentance, past literature claimed that these believers may travel to holy temple out of a sense of responsibility and obligation [17], [23]. [23] also explained that the religious believers visited holy places to preserve their characters and identity, satisfy the feelings of nostalgia, undergo spiritual transcendent or carry out the teachings of the specific belief. Furthermore, [31] also emphasized that religion is the prime motivation for religious tourism. However, religious value is a complicated concept with different layers of meaning and depth depending on the faith of a person and society. [37] explained that the degree of religious belief and tourists' past experiences hold a positive effect on the revisit intention, which means that if the tourists had a positive past experience when visiting the temple, then this will be resulted in the enhancement of the religious beliefs and there is a high possibility that they will revisit the temple again in the future. Regarding promoting the religious sites, marketing officials must be careful and take the sensitivities issues of religion into consideration while enhancing the tourists' experience quality while at the same time also promoting the sacred site as a religious tourist destination. For instance, the services such as an interpretation-history centre that teaches Buddhism or an immersive multi-media show such as 'Walking with Buddha' that demonstrate the life of Siddhartha Gautama [38].

Besides, personal and spiritual growth also positively affected the revisit intention to religious temples at a significant level of $\mathrm{p}<0.01$. Religion and spirituality are very common motivations for religious tourism over the last few decades [1], [24], [31], [40]. [37] explained that spiritual motivations would inspire Buddhist travellers to go for religious holidays to enhance their spiritual involvement with Buddhism. This involves looking for authenticity and genuineness within holy experiences while immersing themselves in a solemn peaceful atmosphere of a Buddhist temple. Religious ceremonies executed at the religious temple also could enhance the spiritual experience of the religious tourists. The ceremonies usually focus on prayers, interacting and chanting with the tourists, long walking trips to the hill, immersing in sacred water, donating, eating simple vegetarian food and tolerating long queues and problems in the temple [36]. Nonetheless, such commercial behaviours should be managed by the marketing officials, the other elements that can enhance the experience of the religious tourists should be increased.

Moreover, the need for social interaction was discovered to be positively correlated with the revisit intention to religious temples at a significant level of $\mathrm{p}<0.05$. According to [31], believers want to interact and socialize with the new or like-minded people but with the same beliefs or faith would joined an organized trip to a holy place. The gathering with fellow devout believers may enhance the existing friendship or create new relationships with the individuals that practice the same religion [37] [38].

However, the aspect of achievements was found to be insignificant to the revisit intention to religious temple for most of the respondents. This could be due to Buddhists were not searching for challenging or adventurous experience, hardship and physical activity while undergoing religious trip. According to [38], religious tourism was anticipated to be challenging and adventurous undertaking that involved hardship as well as a degree of prostration to 
achieve spiritual gratification, but this anticipation was relevant only before the 19th century. Buddhists usually focus on spiritual development; this is in accord with the Buddhism teachings that encourage their believers to focus on spiritual development or growth in present life. Moreover, the two-factor theory of motivation suggested that religious tourists may be motivated to achieve a goal only if they are simultaneously satisfied with hygiene and physical conditions of the holy places, therefore, if the hygiene and physical conditions of the holy places have not been emphasized and improved, then the believers may not be motivated to perform religious tourism due to these factors [31].

Moving on, cultural value was discovered to be an insignificant factor to the revisit intention among the Malaysian Buddhist. This result is inconsistent with the previous studies done by [37] - [38] where cultural value was found to be significant factor. This could be due to the reason that the intrinsic factors have been a more essential motivation for Buddhists in Malaysia. According to [17], cultural value was found to be insignificant is due to the various attitudes and arguments about the purpose of a religious and cultural trip. Religious tourism varies distinctly with the cultural tourism where a trip to value the archaeological memorials and monuments cannot be considered as a religious visit.

\section{RECOMMENDATION FOR FUTURE STUDIES}

This research can be a foundation for future research on religious tourism. Future researches should include moderating factors such as tourist' past experience and the extent of religious belief as essential factors that affected religious tourist motivations [37]. Further research can also be done on categorizing and identifying the push-and-pull factors temple revisits. Push-and-pull motivation framework has always been utilized to guide empirical examinations of tourist motivations [37].

Since there is a rapid growth in the religious tourism sector, the commercial atmosphere around religious sites also increased. Future researches should inspect the effect of this commercial atmosphere on tourist motivation to improve and develop existing instruments. Further studies on the methods to enhance religious tourist satisfaction and revisit intention should also be carried out. Moreover, the correlation between independent variables and dependent variable could be investigated in depth by implementing qualitative research methods such as one-to-one interviews or focus group. Future researches could also conduct qualitative researches to gain a deeper understanding on the rejected hypothesis. Lastly, the tourism sector or government could be invited to participate in further studies. This could help in getting a larger sample size for better representation of the population.

\section{CONCLUSION}

The results of this study may support the government or businessman in expanding the religious tourism sector in Malaysia. The potential consumers should be understood to determine the correct actions in growing this sector. In addition, the limitations in this study should be addressed and improved by the future researches. These researches are expected to deliver useful insights into the religious tourism sector in Malaysia.

In conclusion, a careful and continuous study is essential to keep up with the increasing trend in this blooming sector. The lack of study in this niche market makes it hard to inspect the development of religious tourism since the old age of pilgrimage. The policy makers, tourism sector and local communities require in-depth insights regarding the motivational factor of religious tourism to enhance the quality of the tourist experience which later will contribute to the revisit intention from the Buddhism perspectives in Malaysia.

\section{ACKNOWLEDGMENT}

This paper has been presented in the International Conference and Business Sustainability and Innovation 2018 (ICBSI 2018).

\section{REFERENCES}

[1] Amaro, S., Antunes, A., \& Henriques, C. (2018). "A closer look at Santiago de Compostela's pilgrims through the lens of motivations". Tourism Management, 64, 271-280.

[2] Antunes, A., Amaro, S., \& Henriques, C. (2017). "Motivations for Pilgrimage: Why pilgrims travel El Camiño de Santiago".

[3] Aziz, H. (2001). "The journey: An overview of tourism and travel in the Arab/Islamic context". In Tourism and the Less Developed World: Issues and Case Studies, UK: CABI Publishing, ch. 10, pp. 151-160.

[4] Bader, M. (2012). "Religious tourism in Jordan: current situation, future developments and prospects: a case study on Islamic and Christian holy sites," Ph.D. dissertation, Faculty of Mathematics and Geography, Catholic University of Eichstaett-Ingolstadt, Eichstätt, Germany.

[5] Barbeitos, I. M., do Valle, P. O., Guerreiro, M., \& Mendes, J. (2014). "Visitors' Motivations, Satisfaction and Loyalty towards Castro Marim Medieval Fair". Journal of Spatial and Organizational Dynamics, 2(1), 89-104.

[6] Battour, M. M., Battor, M. M., \& Ismail, M. (2012). "The mediating role of tourist satisfaction: A study of Muslim tourists in Malaysia". Journal of Travel \& Tourism Marketing, 29(3), 279-297.

[7] Campón, Ana María, Helena Alves, and José Manuel Hernández (2013). "Loyalty measurement in tourism: A theoretical reflection." In Quantitative methods in tourism economics, Physica, Heidelberg, pp. 13-40.

[8] Cohen, E. (2006). "Religious tourism as an educational experience". In Tourism, Religion and Spiritual Journeys, 1 st ed. New York: Routledge, ch. 6, pp. 78-93.

[9] Davies, D. (1994). Christianity. In Sacred place, New York: Continuum, ch. 2, pp. 33-61.

[10] Division, U. N. S. (2010). "International Recommendations for Tourism Statistics 2008: United Nations Publications".

[11] Gurung, R. (2016). "Marketing Religious Tourism Destination: Case study: The birth place of Gautama Buddha, Lumbini, Nepal," Bachelor's Thesis, Centria University of Applied Sciences. Retrieved http://www.theseus.fi/handle/10024/114293.

[12] Hair Jr, J. F., Hult, G. T. M., Ringle, C., \& Sarstedt, M. (2016). A primer on partial least squares structural equation modeling (PLS-SEM): Sage Publications.

[13] Hall, C. M. (2006). "Buddhism, tourism and the middle way". In Tourism, religion and spiritual journeys, New York: Routledge, ch. 12, pp. 172-185.

[14] Henseler, J., Ringle, C. M., \& Sarstedt, M. (2015). “A new criterion for assessing discriminant validity in variance-based structural equation modeling". Journal of the Academy of Marketing Science, 43(1), 115-135.

[15] Herzberg, F. (1974). Work and The Nature of Man. St Albans, UK: Granada Publishing Ltd.

[16] Hughes, K., Bond, N., \& Ballantyne, R. (2013). "Designing and managing interpretive experiences at religious sites: Visitors' 
perceptions of Canterbury Cathedral". Tourism Management, 36, 210-220

[17] Iheanacho, N. N. (2015). "Nigerian praxis of religious tourism and pilgrimage motivations in the globalizing world". Revista Ciências da Religião-História e Sociedade, 13(1).

[18] Kamarudin, L. M., \& Nizam, H. (2013, February). "Islamic Tourism: The Impacts to Malaysia's Tourism Industry". Presented at the International Conference of Tourism Development, 397

[19] Kamenidou, I., \& Vourou, R. (2015). "Motivation factors for visiting religious sites: The case of Lesvos Island". European Journal of Tourism Research, 9, 78.

[20] Konu, H., \& Laukkanen, T. (2009). "Roles of motivation factors in predicting tourists' intentions to make wellbeing holidays - a Finnish case". Australian \& New Zealand Marketing Academy Conference 2009 (ANZMAC 2009).

[21] Luc Vérain. (2015, May). "Tourist Motives, Expectations and Satisfaction" M.S. thesis. Retrieved from http://edepot.wur.nl/343833

[22] Madhu, A., Himanshu, C., \& Gaurav, T. (2010). "Enhancing Buddhist tourism in India: an exploratory study". Worldwide Hospitality and Tourism Themes, 2(5), 477-493.

[23] Musawenkosi, A. L. (2010). "An Investigation of Religious Tourism: A Case Study of Quigney Baptist Church (East London, Eastern Cape, South Africa)". Faculty of Business, Management Sciences \& Law. Walter Sisulu University, East London.

[24] Nieminen, K. (2012). "Religious tourism-a Finnish perspective" M.S. thesis. Haaga-Helia University of Applied Sciences. Retrieved from www.theseus.fi/handle/10024/51755

[25] Olsen, D., \& Timothy, D. (2006). "Tourism and religious journeys". In Tourism, Religion and Spiritual Journeys, 1st ed. New York: Routledge, ch. 1, pp. 1-21.

[26] Özkan, C. (2013). "The Convergence or Divergence of Pilgrimage and Tourism in Modern China". International Journal of Social Inquiry, 6(2).

[27] Pearce, P. L. (2005). Tourist Behaviour: Themes and Conceptual Schemes, Great Britain: Channel View Publications.

[28] Pew Research Center. (2017, April 5). "Christians remain world's largest religious group, but they are declining in Europe".

[29] Phan, T. K. L. (2010). "Tourist motivation and activities: a case study of Nha Trang, Vietnam" M.S. thesis, Norwegian College of Fishery Science, University of Tromsø, Norway and Nha Trang University, Vietnam.

[30] Plante, T. G. (2010). "The Santa Clara Strength of Religious Faith Questionnaire: Assessing faith engagement in a brief and nondenominational manner". Religions, 1(1), 3-8.

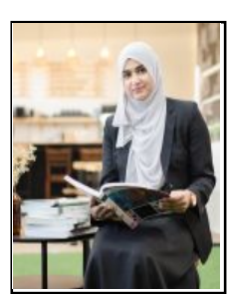

Siti Hasnah Hassan was born in Pahang, Malaysia. She completed her $\mathrm{PhD}$ at the Australian National University in 2009 .

Currently, she is a senior lecturer in the Marketing Section, School of Management, Universiti Sains Malaysia. Her research interest areas include sustainable consumption behaviour, convergence and divergence of consumer behaviour, Islamic marketing and branding, food marketing, medical and spiritual tourism. She published in local and international journals.

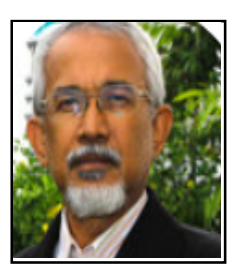

Osman Mohamad is a professor at Faculty of Management, Multimedia University. His research interest areas include marketing and economics.
[31] Raj, R., \& Griffin, K. (2015). Religious Tourism and Pilgrimage Management: An International Perspective, 2nd ed. United Kingdom: CAB International, ch. 7, pp. 103-116.

[32] Rodriguez, J. (2017). "Cleaning Up Bodhgaya: Conflicts over Development and the Worlding of Buddhism". City \& Society, 29(1), 59-81.

[33] Shafaei, F., \& Mohamed, B. (2017). "Malaysia's branding as an Islamic tourism hub: An assessment". Geografia-Malaysian Journal of Society and Space, 11(1).

[34] Sharpley, R. (2009). Tourism, religion and spirituality. The Sage handbook of tourism studies, pp. 237-253.

[35] Sharpley, R., \& Sundaram, P. (2005). "Tourism: A sacred journey? The case of ashram tourism, India". International Journal of Tourism Research, 7(3), 161-171.

[36] Vinnie, J., \& M., S. G. (2010). "Managing customer experience for spiritual and cultural tourism: an overview". Worldwide Hospitality and Tourism Themes, 2(5), 467-476.

[37] Wang, W., Chen, J. S., \& Huang, K. (2016). "Religious tourist motivation in Buddhist mountain: The case from China". Asia Pacific Journal of Tourism Research, 21(1), 57-72.

[38] Wong, C. U. I., Ryan, C., \& McIntosh, A. (2013). "The Monasteries of Putuoshan, China: Sites of secular or religious tourism?". Journal of Travel \& Tourism Marketing, 30(6), 577594.

[39] Yoon, Y., \& Uysal, M. (2005). "An examination of the effects of motivation and satisfaction on destination loyalty: a structural model". Tourism Management, 26(1), 45-56.

[40] Yu, W., \& Phakdee-auksorn, P. (2016). "Understanding Chinese Tourists' Motivations for Visiting Buddhism-Related Attractions in Phuket, Thailand". Journal of International Studies, 6(1), 73107.

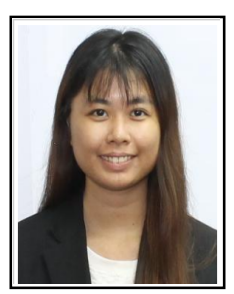

Teo Shao Zhen was born in Kelantan, Malaysia. She completed her Bachelor of Management from Universiti Sains Malaysia in 2018, majoring in organizational behavior and minoring in psychology.

Currently, she is a Master of Arts (Management) student in School of Management, Universiti Sains Malaysia. She also working as the Graduate Research Assistant with her supervisor. Her research interest is in Entrepreneurship. 